\title{
Christine Ferlampin-Acher, Daphné dans les textes français du Moyen Age: des amours réticentes
}

\section{G. Matteo Roccati}

\section{(2) OpenEdition}

\section{Journals}

Édition électronique

URL : http://journals.openedition.org/studifrancesi/9116

DOI : 10.4000/studifrancesi.9116

ISSN : 2427-5856

Éditeur

Rosenberg \& Sellier

\section{Édition imprimée}

Date de publication : 1 juin 2008

Pagination : 160-161

ISSN : 0039-2944

\section{Référence électronique}

G. Matteo Roccati, «Christine Ferlampin-Acher, Daphné dans les textes français du Moyen Age: des amours réticentes », Studi Francesi [En ligne], 154 (LII | I) | 2008, mis en ligne le 30 novembre 2015, consulté le 13 janvier 2021. URL : http://journals.openedition.org/studifrancesi/9116 ; DOI : https:// doi.org/10.4000/studifrancesi.9116

Ce document a été généré automatiquement le 13 janvier 2021.

\section{(c) $(1)$}

Studi Francesi è distribuita con Licenza Creative Commons Attribuzione - Non commerciale - Non opere derivate 4.0 Internazionale. 


\title{
Christine Ferlampin-Acher, Daphné dans les textes français du Moyen Age: des amours réticentes
}

\author{
G. Matteo Roccati
}

\section{RÉFÉRENCE}

CHRISTINE FERLAMPIN-ACHER, Daphné dans les textes français du Moyen Age: des amours réticentes, «Cahiers de l'Association Internationale des Études Françaises», mai 2006, n. 58, pp. 291-308.

1 Le mythe, la métamorphose de Daphné en laurier, est en apparence peu répandu et a été repris seulement au début du XIV siècle dans l'Ovide moralisé, puis dans L'Espinette amoureuse et Le Joli Buisson de Jonece de Froissart, enfin dans l'Epitre Othea de Christine de Pizan. Après avoir parcouru ces textes, l'A. essaye de déterminer les raisons de la réticence des auteurs médiévaux face à la métamorphose végétale. Elle relève en particulier la concurrence d'autres représentations qui mêlent l'arbre et l'humain: l'arbre de Jessé, le songe d'Astyage (tiré d'Hérodote et qui apparaît notamment chez Vincent de Beauvais), le Christ en croix, les arbres de type généalogique, le serpent de la tentation dans l'arbre du péché originel. En conclusion elle montre que, malgré cette réticence, en fait le mythe était connu: en témoignent son utilisation dans le Lai de Narcisse - repris dans le roman de Cristal et Clarie - et les allusions, qui demeurent implicites, qu'on trouve dans Perceforest. 